\title{
Relation Significance between Hydrological Residence Time and Phytoplankton Dynamics in Lake Kinneret (Israel)
}

\author{
Moshe Gophen \\ Migal-Scientific Research Institute, Kiryat Shmone, Israel \\ Email: Gophen@Migal.org.il
}

How to cite this paper: Gophen, M. (2019) Relation Significance between Hydrological Residence Time and Phytoplankton Dynamics in Lake Kinneret (Israel). Open Journal of Ecology, 9, 479-492.

https://doi.org/10.4236/oje.2019.911031

Received: September 28, 2019

Accepted: October 28, 2019

Published: October 31, 2019

Copyright $\odot 2019$ by author(s) and Scientific Research Publishing Inc. This work is licensed under the Creative Commons Attribution International License (CC BY 4.0).

http://creativecommons.org/licenses/by/4.0/

\begin{abstract}
Long-term data record of Phytoplankton (Peridinium, Cyanophyta, Chlorophyta, Diatoms) dynamics in Lake Kinneret was evaluated comparatively with hydrological parameters. The hydrological features were found to be correlated with algal biomass distribution. Consequently, the best representor of the hydrological trait, Residence Time, is suggested to be a key parameter controlling algal dynamics.
\end{abstract}

\section{Keywords}

Kinneret, Phytoplankton, Residence Time

\section{Introduction}

Lake Kinneret and its watershed are a part of the Northern section of the Syrian-African great rift Valley. The Lake Kinneret Watershed area $\left(2730 \mathrm{~km}^{2}\right)$, is stretched between $32^{\circ} 40^{\prime}$ and $33^{\circ} 38^{\prime}$ North, $110 \mathrm{~km}$ long N-S axis. The Kinneret drainage basin has a high altitude gradient: from +2814 (masl) to $-214 \mathrm{~m}$ (bsl). Lake Kinneret is situated between latitudes $32^{\circ} 42^{\prime} 15^{\prime \prime}$ North and $32^{\circ} 53^{\prime} 44^{\prime \prime}$ North and longitudes $35^{\circ} 30^{\prime} 52^{\prime \prime}$ and $35^{\circ} 38^{\prime} 55^{\prime \prime}$ East.

A vast number of scientific papers documenting research about the eco-physiological features of the Phytoplankton in Lake Kinneret were published [1]-[6]. These studies were mostly focused on the relations between specific chemical (nutrients) and Phytoplankton [7]-[17] or physical conditions, such as temperature and sun radiation or water mass motions [18]-[29], and zooplankton or fish grazing [21] [22]. Nevertheless, the issue of direct linkage or affinity between hydrological parameters and algal community structure is scarce. Moreover, most of the early studies are aimed directly at the significance of the affinity of 
the algae to nutrients. The advancement of the investigation processes to a further step of the linkage to hydrology is not very common in earlier studies. The present paper is aimed at an attempt to correlate phytoplankton dynamics to hydrological traits and use the nutrient as a speculative tool for this linkage. The selected parameter from the hydrological trait is Water Residence Time, which is obviously integrated inside the entire water balance frame.

\section{Material and Methods}

The data sources for this study, 1969-2001, are the followings: Lake Information: LKDB-Lake Kinneret Data Base, Kinneret Limnological Laboratory, IOLR [1]; Hydrological properties: Mekorot, Water Supply Co. Data evaluations presented in this paper include: Phytoplankton distributed densities and TN (Total Nitrogen) and TP (Total Phosphorus) distribution in the Epilimnion of Lake Kinneret and Hydrological properties: Lake Volume, Total water inflow, WL (Water Level) monthly changes, RT (Residence Time) values. Statistical evaluation methods include simple averaging and Linear (between $X$-independent and $Y$-dependant parameters: $\left.Y=a X+b ; r^{2}>0.3, \mathrm{p}<0.01\right)$ and Fractional Polynomial Regressions (STATA .9. Reference A-J pp. 357-370).

Residence Time computation is based on the following equation:

$W=$ Monthly inflow in $\mathrm{mcm}$ per month $\left(10^{6} \mathrm{~m}^{3} / \mathrm{month}\right)$.

$V=$ Monthly values of lake Volume in $\mathrm{mcm}\left(10^{6} \mathrm{~m}^{3}\right)$.

$\mathrm{RT}=V / W$ per month in months or years.

\section{Results and Discussion}

General scheme of temporal (monthly) trend of changes of Phytoplankton dynamics as linearly predicted by Nutrients: Epilimnetic loads of TN and TP, and TN/TP mass ratios in the Epilimnion (Figure 1); Phytoplankton dynamics influenced by Hydrological properties: Water inflows, and Residence Time (Figure 2 ), WL monthly changes (Figure 3 ). Results given in Figure 1(A) indicate TN stock limitation for Peridinium but not for Cyanophyta, Diatoms and Chlorophyta. Figure 1(B) indicates TP stock limitation for Peridinium and Diatoms but not for Chlorophyta. Figure $1(\mathrm{C})$ indicates that the decline of TN/TP mass ratio in the Epilimnion, where Phytoplankton is accommodated, reflects TN decrease and TP elevation [23] [24], which is a combined condition not favored by all algal groups. Figure 2 indicates TN, TP and, to a lesser extent, TN/TP mass ratio elevation predicted responses to the enhancement of Water inflows. It probably characterized the situation during heavy winter floods. RT prolongation (Figure 2) occurs when water inflows decline and, consequently, TN declines and Peridinium, the ultimate consumer of Nitrogen, reduces as well. Moreover, RT prolongation also responded by Diatom's decline. It is likely that not only does Nitrogen availability decline but also another element deficiency occurs, probably Silica. Diatoms require Silica, and when Silica reduces, Diatoms decline as well. Peridinium and Diatoms are both dependants of outsourcing elemental supply, of Nitrogen and Silica [4]. Nevertheless, Chlorophyta 

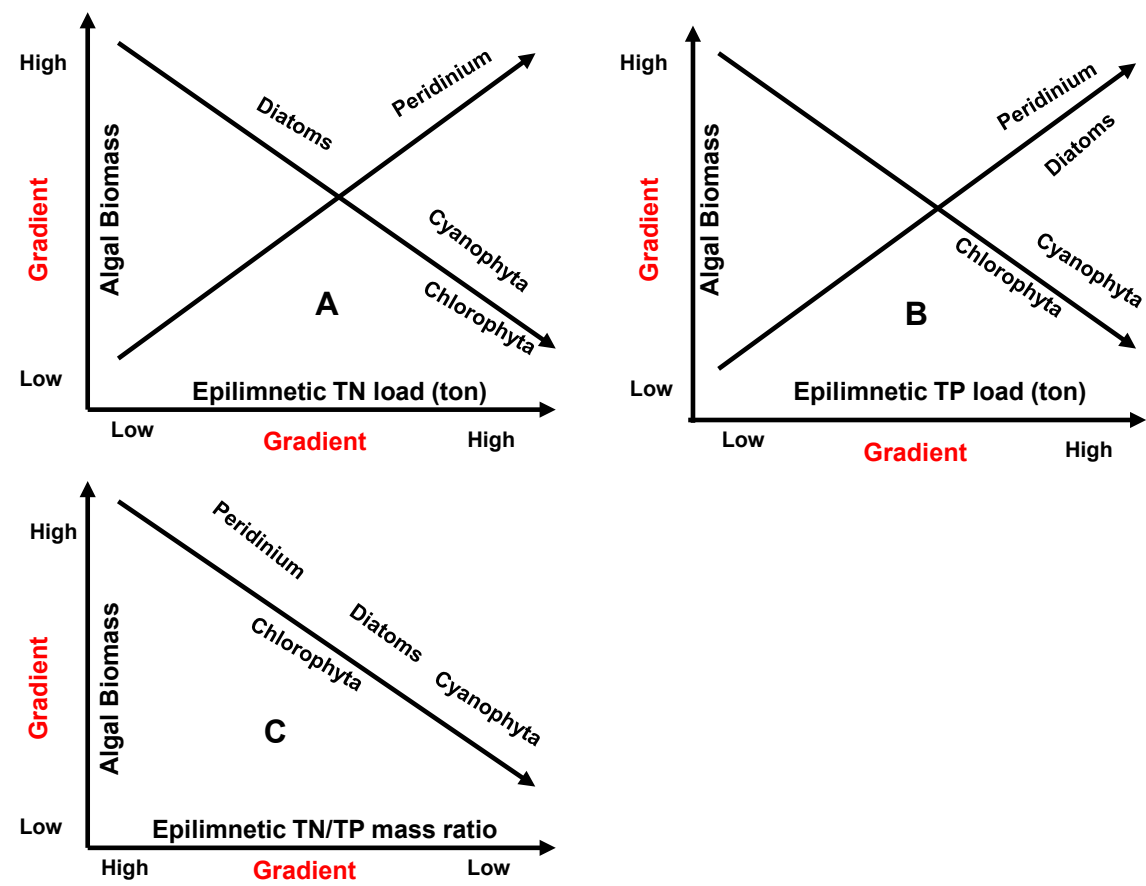

Figure 1. Trend of changes as Linear regression between Phytoplankton (Peridinium, Diatoms, Chlorophyta, Cyanophyta) biomass and Epilimnetic Nutrient (TN, TP,) stock (ton) increase and TN/TP mass ratio decline (1969-2001).
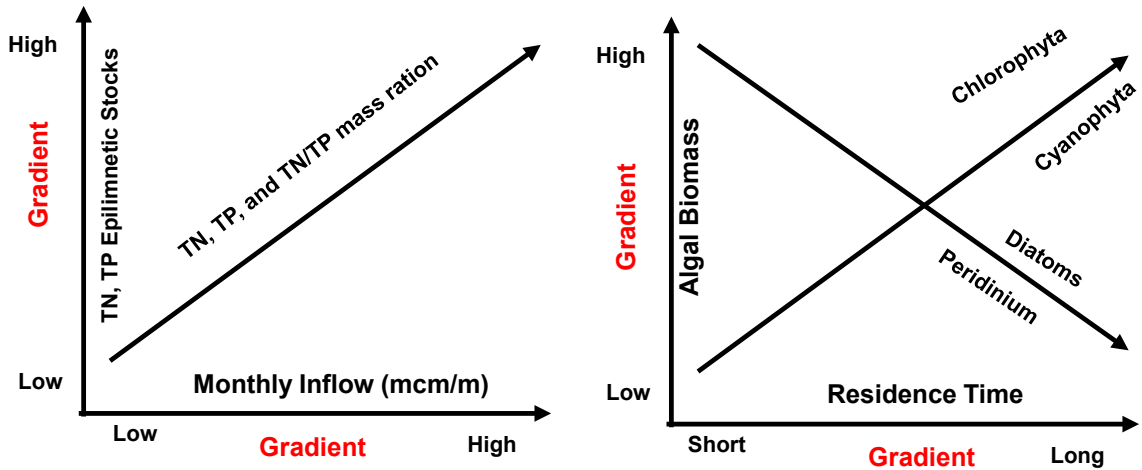

Figure 2. Trend of changes as Linear regression between Epilimnetic Nutrient stocks and TN/TP mass ratio in response to Water Inflows increase (Left Panel) and Phytoplankton (Peridinium, Diatoms, Chlorophyta, Cyanophyta) biomass In response to RT elongation (Right Panel) (1969-2001).

and Cyanophyta rely on internal or atmospheric dustfall P-supply (Chlorophyta) [25]-[29], or atmospheric N-fixation (Cyanophyta) [11] [12] [16] [17] [30]. Figure 3 indicates an enhancement of Peridinium and Diatoms in relation to WL and a similar response between WL and RT changes. The elevation of WL is accompanied by shorter RT and vice versa.

Long-term FP (Fractional Polynomial) evaluation of monthly RT (Residence Time) values indicates (Figure 4) significant increase since the mid-1970's from 7.1 to 9.1 years (see methods). This trend of change is likely to be caused by reduction of inflows or decline of outflow accompanied by lake volume elevation 


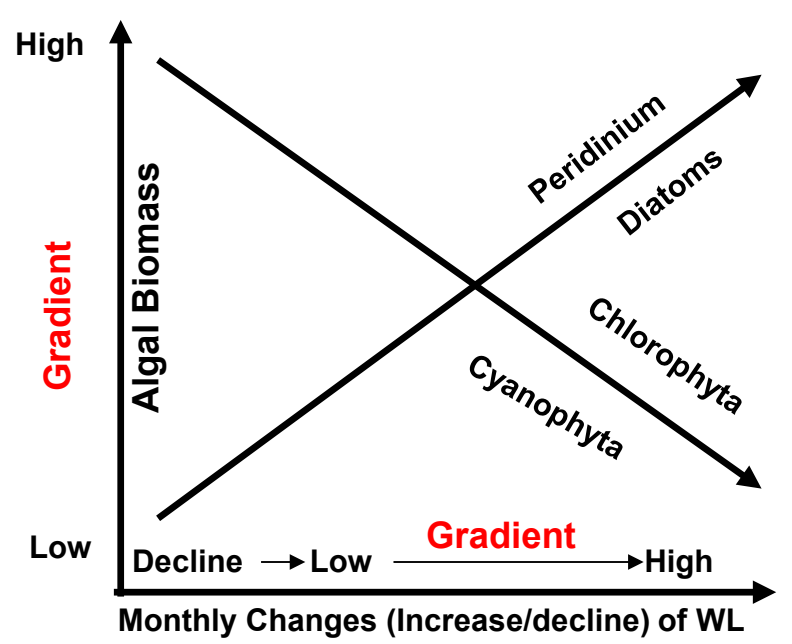

Figure 3. Trend of changes as Linear regression between Phytoplankton (Peridinium, Diatoms, Chlorophyta, Cyanophyta) biomass in response to monthly changes (increase-decline) of Water Level (1969-2001).

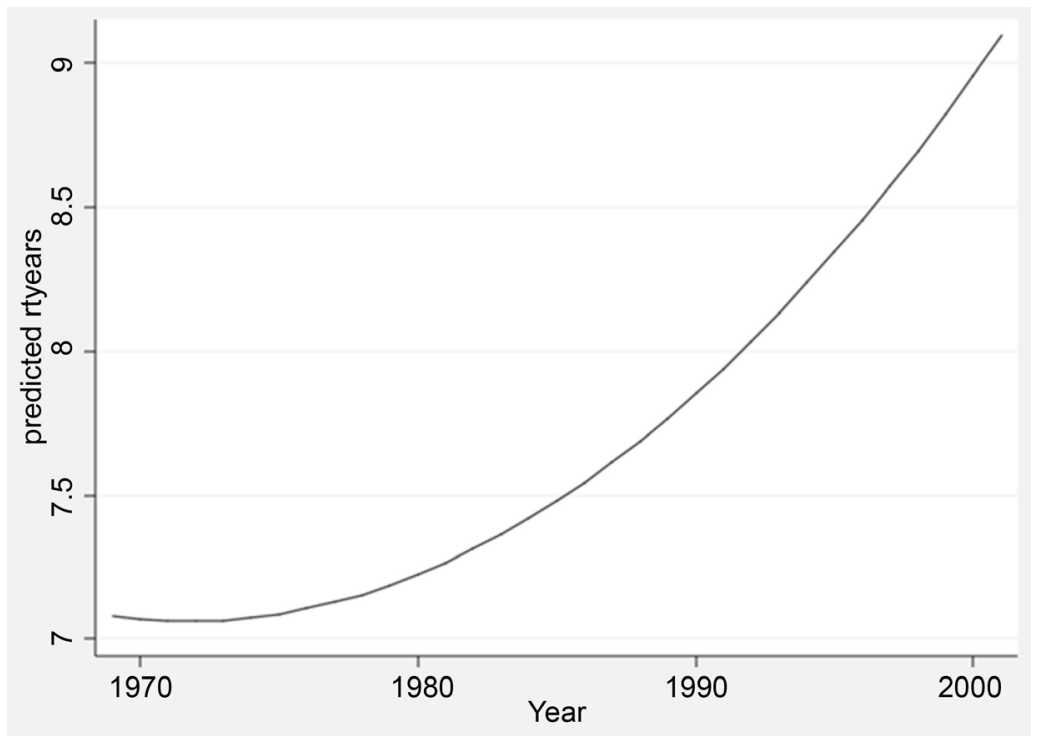

Figure 4. FP (Fractional Polynomial) regression (Stata 9 Reference A-J, pp. 357-370) between Annual means of monthly RT (Residence Time; few cases of RT > 20 years were eliminated) and years (1969-2001).

or a combination of both. The hydrological features of Lake Kinneret are probably indicated as principal conditional parameters affecting Phytoplankton dynamics (Figures 1-3). Moreover, FP evaluation of multi-annual (1969-2001) averages of monthly RT values (Figure 4) confirm this definition of the natural trend of RT values: trend of multiannual increase (Figure 4) and seasonal prolongation trend from December to September next year (Figure 5), which corresponds to the natural Hydrological cycle (Figures 5-9): from May, Inflow declines after earlier elevation (Figure 6), Lake Volume is reduced from September after an earlier increase (Figure 7), trend (FP) of Inflow decline from January to September following earlier increase (Figure 8), and finally (Figure 9) trend 


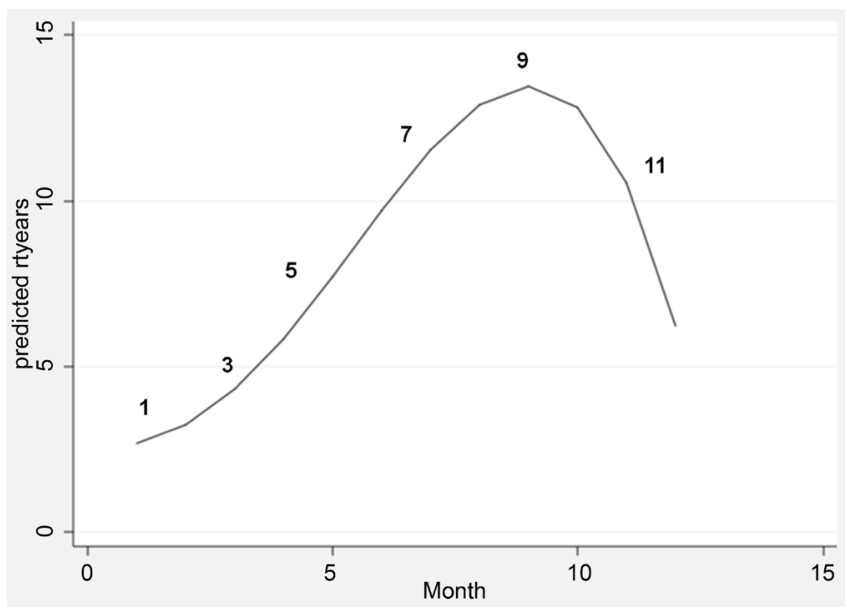

Figure 5. FP (Fractional Polynomial) regression between Seasonal (months are indicated 1 - 12) and fluctuations of RT (Residence Time in years); (few cases of RT $>20$ years were eliminated) (1969-2001).

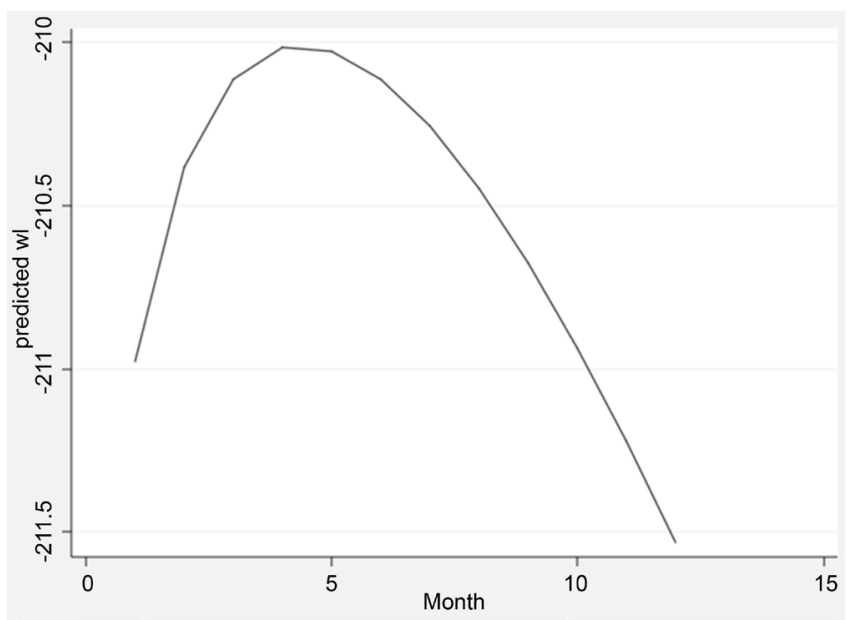

Figure 6. FP (Fractional Polynomial) regression of Monthly fluctuations of lake water level (mbsl) (1969-2001).

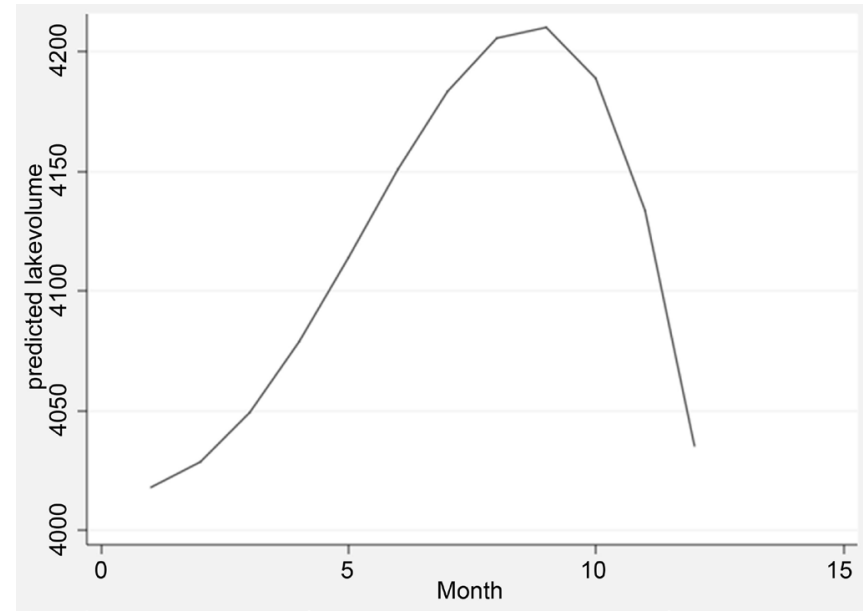

Figure 7. FP (Fractional Polynomial) regression of Monthly fluctuations of lake volume $\left(10^{6} \mathrm{~m}^{3}\right)(1969-2001)$. 


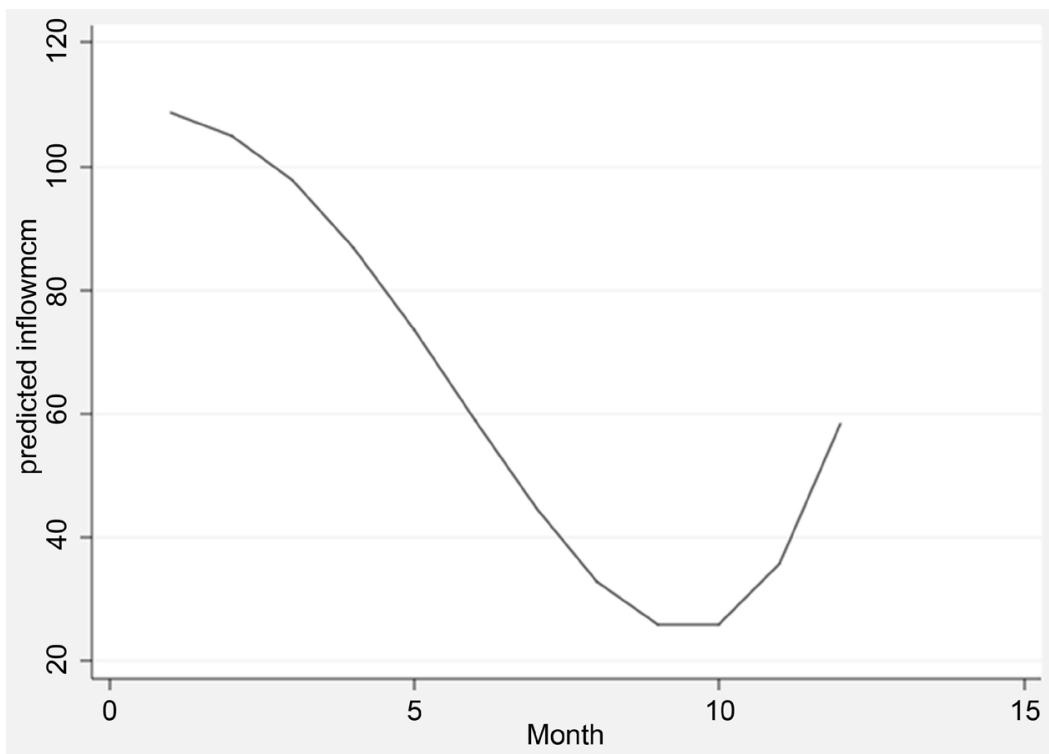

Figure 8. FP (Fractional Polynomial) regression of Monthly fluctuations of monthly inflows $\left(10^{6} \mathrm{~m}^{3}\right)(1969-2001)$.

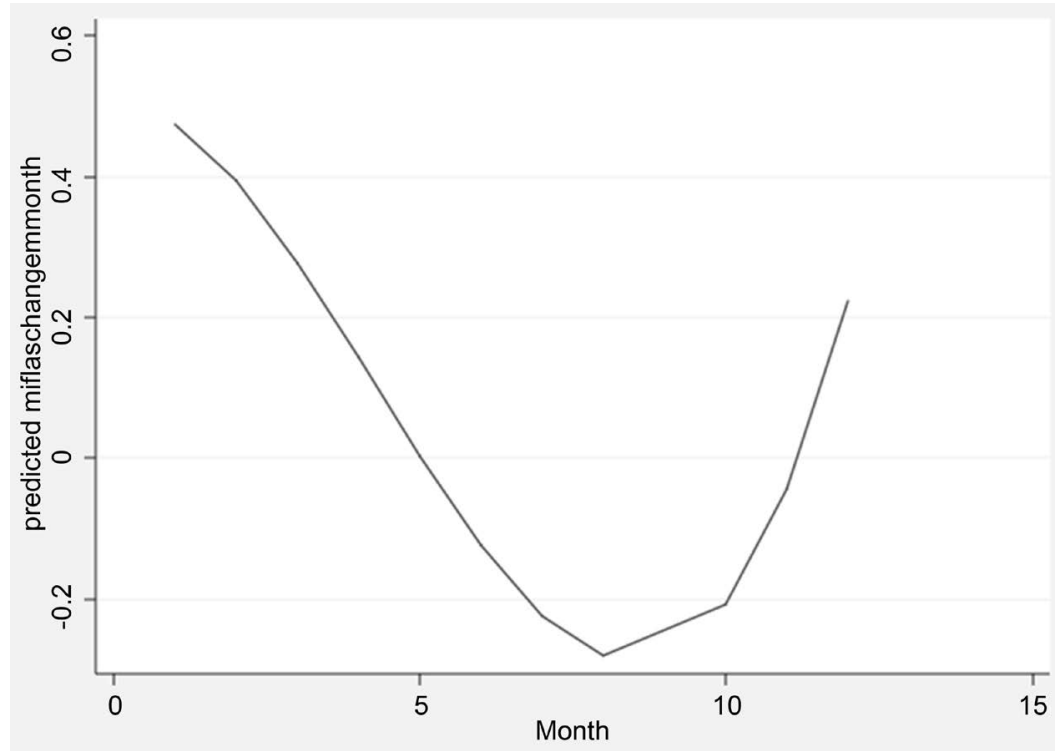

Figure 9. FP (Fractional Polynomial) regression of Monthly fluctuations of monthly changes of Water Level (m) (1969-2001).

(not a point value) of WL decline from January to August followed by trend (FP) of increase. The monthly changes of WL were averaged annually, and FP regression was evaluated with the respective RT values (Figure 10). Heavy floods (inflow) obviously correspond with WL increase $(0.31-0.49 \mathrm{~m} / \mathrm{month}$ ) (Figure 10 ), while there is more decline in monthly changes in WL, later followed by $\mathrm{WL}$ lowering, both of which are related to RT prolongation (Figure 10). RT value longer than 7 years is respectively correlated with lower monthly WL change (Figure 10). The natural Hydrological cycle is likely to be in accordance with Phytoplankton dynamics. Therefore, further evaluation is aimed at identifying 


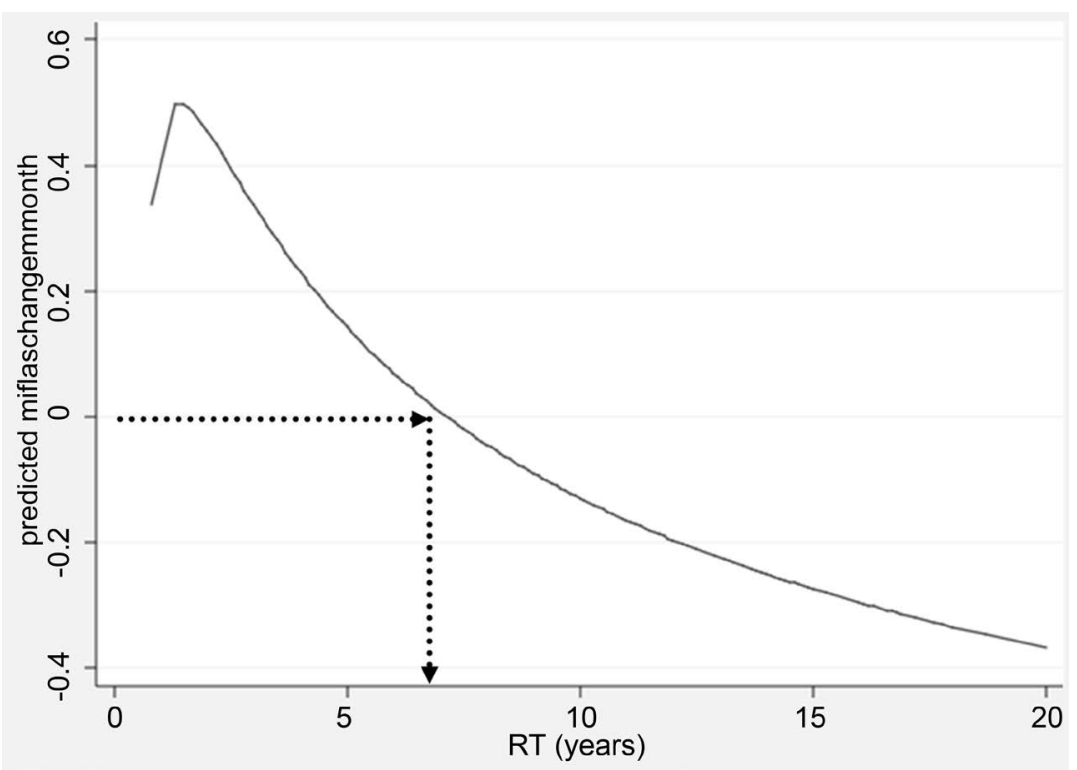

Figure 10. FP (Fractional Polynomial) regression between RT length (Years) and monthly changes of Water Level (m) (1969-2001).

the driving forces that govern the long-term trends that have been presented in Figures 1-3.

The impact of Hydrology on Nutrients and Phytoplankton Dynamics

Monthly changes of Epilimnetic TN stock are shown in Figure 11. Inflow and WL decline while Lake Volume elevation and RT prolongation (Figures 5-10) are correlated with the Epilimnetic load decline of TN. Results presented in Figure 12 indicate an increase of Epilimnetic TP loads during January-April and gradual decline later on until December and correlated with the temporal level of Hydrological parameters as follows (Figures 5-10): RT prolongation during January-September, shortened later; WL increase during January-May and later decline, which is obviously a similar trend to Lake Volume, WL changes and Inflow fluctuations. The seasonal changes of Epilimnetic TN/TP mass ratio (Figure 13) indicate a decline from January to May and a later elevation. The respective relations between TN, TP and TN/TP mass ratio and Hydrological conditions (extracted as RT length) are given in Figure 14. The decline of TN/TP Mass ratio is respective to the prolongation of RT length; a steep decline is correlated to a very slight reduction of RT length and a gradual low decrease in RT prolongation (Figure 14). The higher the RT value is, the lower the Epilimnetic TN/TP mass ratio. Moreover, during the short winter/spring season, the Peridinium bloom is maximal, and P-mediated input is intensive and the change of RT length is minimal due to hydrological enhancement. The decline of TN/TP mass ratio is attributed mostly to phosphorus enhancement. Nevertheless, later on the TN/TP mass ratio decline is also attributed to Nitrogen load decline and RT prolongation caused by diminished Hydrology. The biomass of Peridinium contributes Phosphorus (Figure 15) and the Hydrological carrier contributes Nitrogen. The shortest RTs were recorded during the Peridinium bloom onset and 


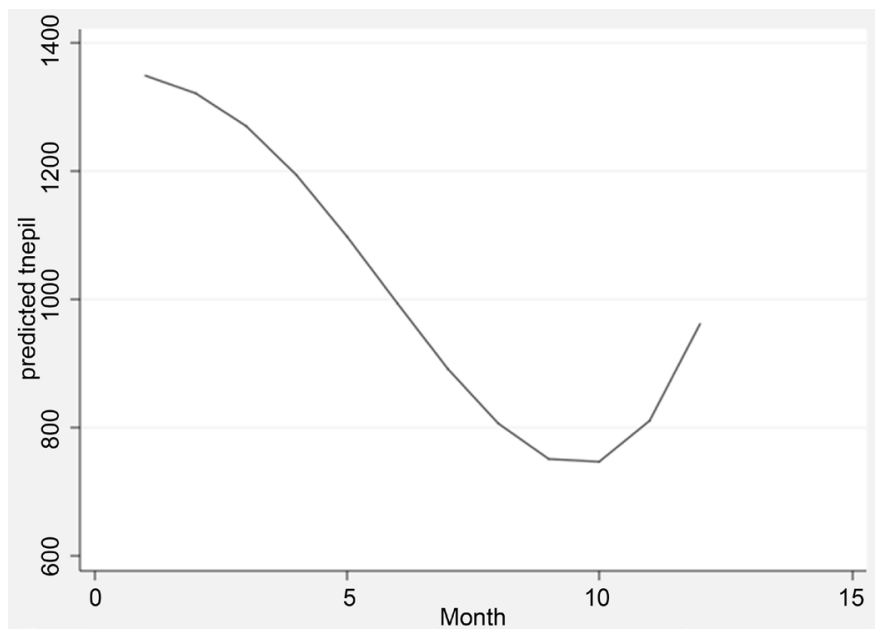

Figure 11. FP (Fractional Polynomial) regression of Monthly fluctuations of Epilimnetic TN stock (ton) (1969-2001).

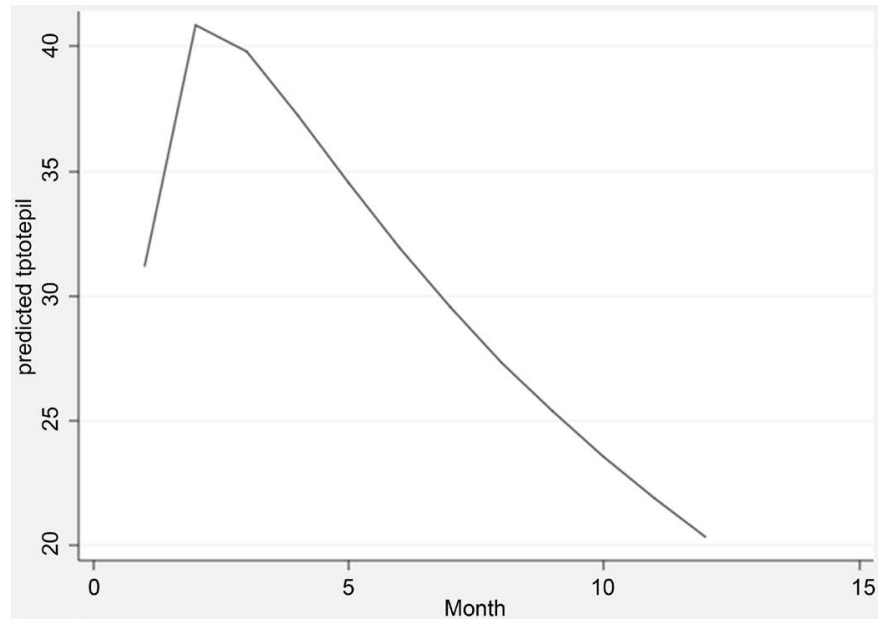

Figure 12. FP (Fractional Polynomial) regression of Monthly fluctuations of Epilimnetic TP stock (ton) (1969-2001).

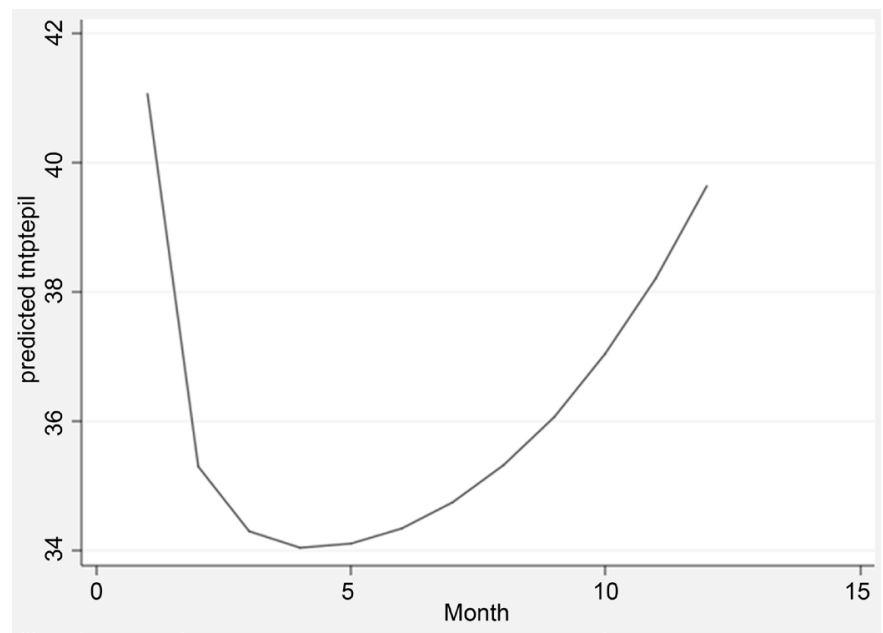

Figure 13. FP (Fractional Polynomial) regression of Monthly fluctuations of Epilimnetic TN/TP mas ration (1969-2001). 


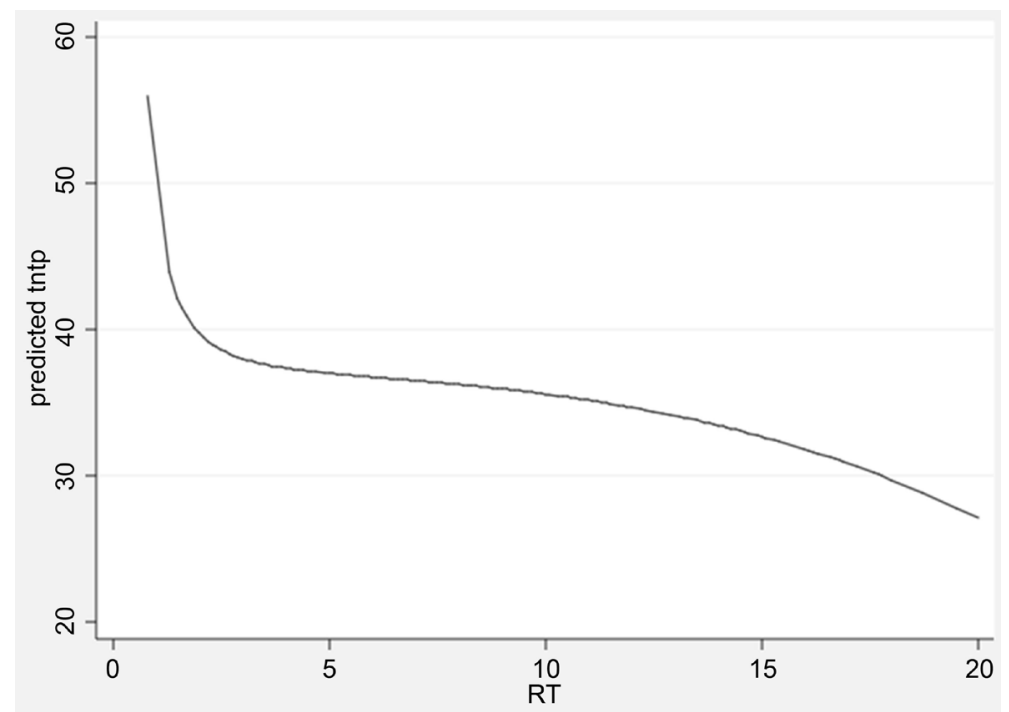

Figure 14. FP (Fractional Polynomial) regression between RT length (Years) and Epilimnetic TN/TP mass ratio (1969-2001).

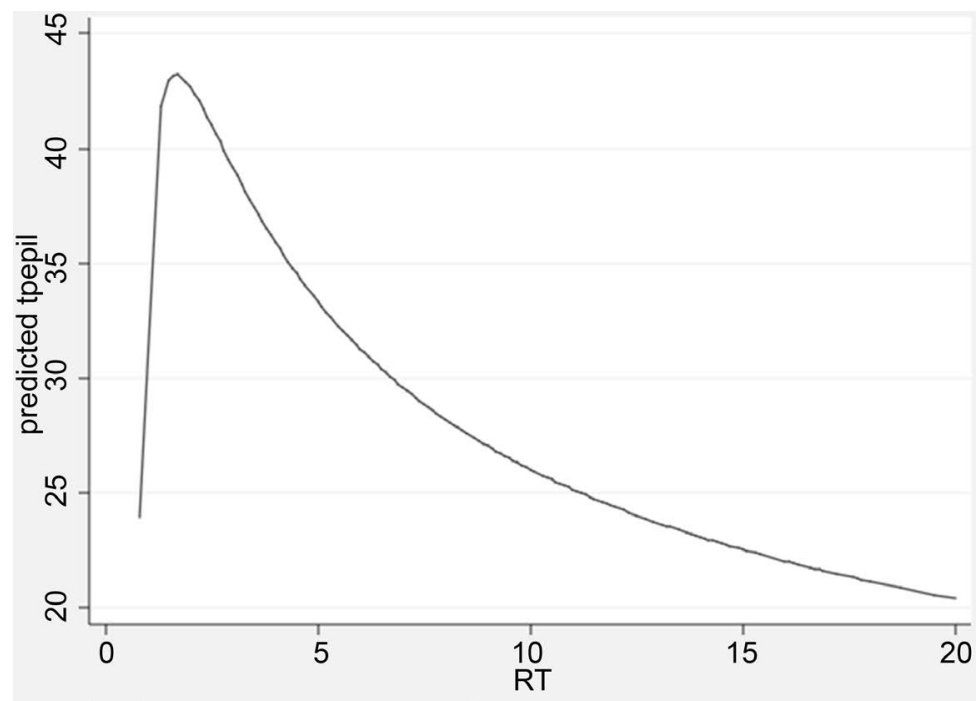

Figure 15. FP (Fractional Polynomial) regression between RT length (Years) and Epilimnetic TP load (ton) (1969-2001).

later when RT length declines, P-mediated Peridinium dissipates, and Epilimnetic stock diminishes. Shortest RTs were recorded during winter, and later in the year RT becomes longer (Figure 16).

Conclusively, algal dynamics relate to RT length as follows (Figures 17-20):

Peridinium (Figure 17): Prolongation of RT corresponds to the reduction of the Peridinium biomass. The prolongation of RT is a signal of Nitrogen availability deficiency and the slight increase of Peridinium biomass during the longest RT, which is probably attributed to Nitrogen input by fixation carried out by Cyanobacteria.

Diatoms (Figure 18): During short RT (1 - 4 years, Figure 18), due to intensive inflows and other Hydrological parameters, Diatom biomass is abruptly enhanced. 


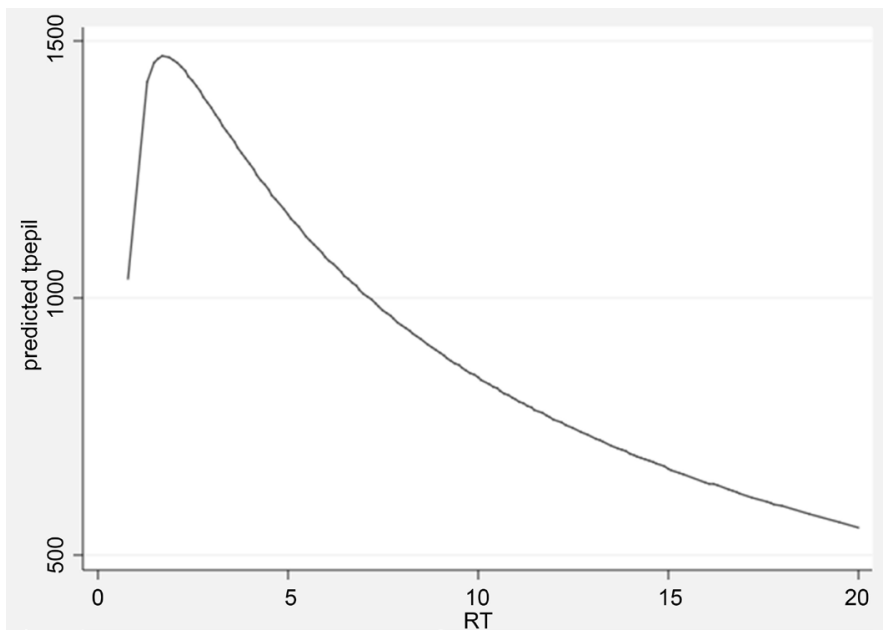

Figure 16. FP (Fractional Polynomial) regression between RT length (Years) and Epilimnetic TN load (ton) (1969-2001).

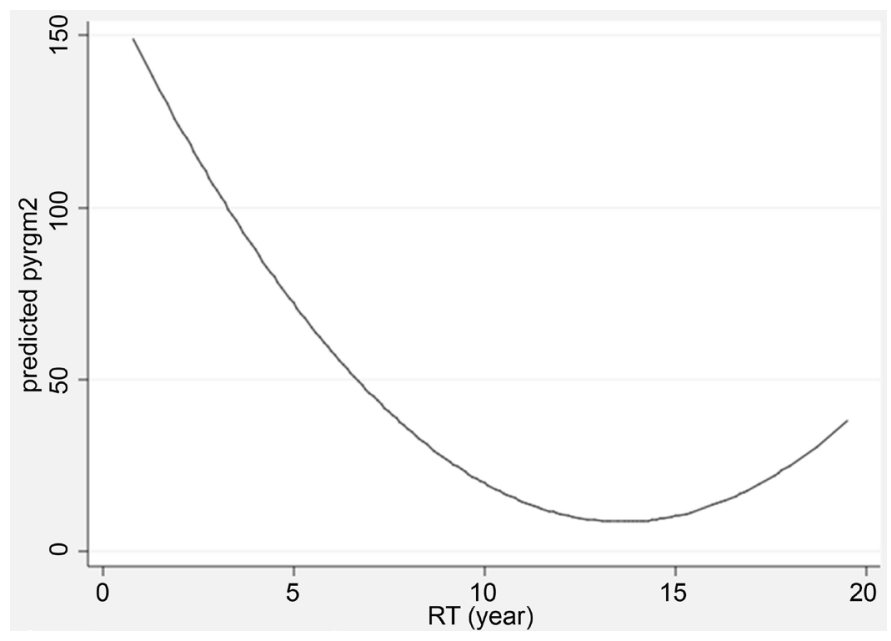

Figure 17. FP (Fractional Polynomial) regression between RT length (Years) and Peridinium Biomass $\left(\mathrm{g} / \mathrm{m}^{2}\right)(1969-2001)$.

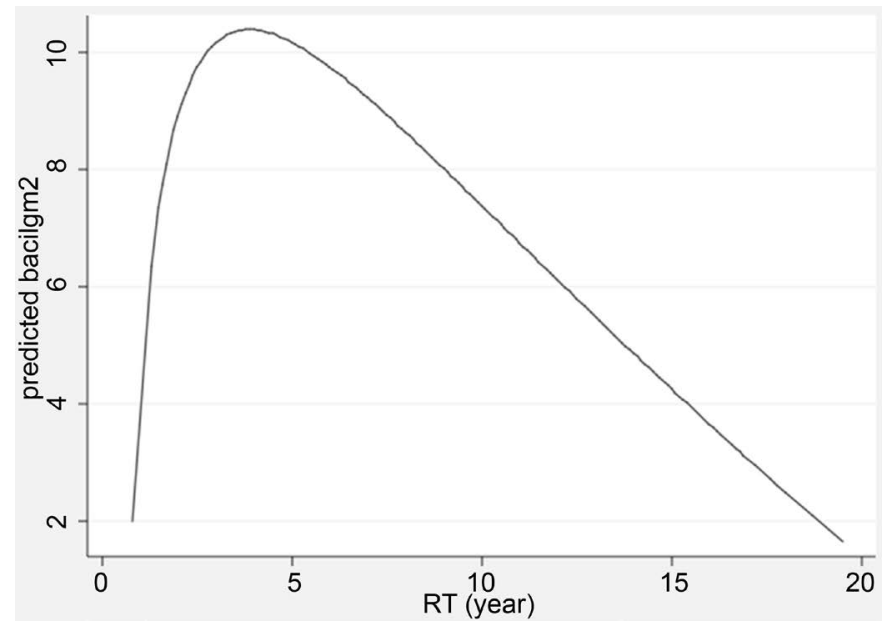

Figure 18. FP (Fractional Polynomial) regression between RT length (Years) and Diatoms Biomass $\left(\mathrm{g} / \mathrm{m}^{2}\right)(1969-2001)$. 


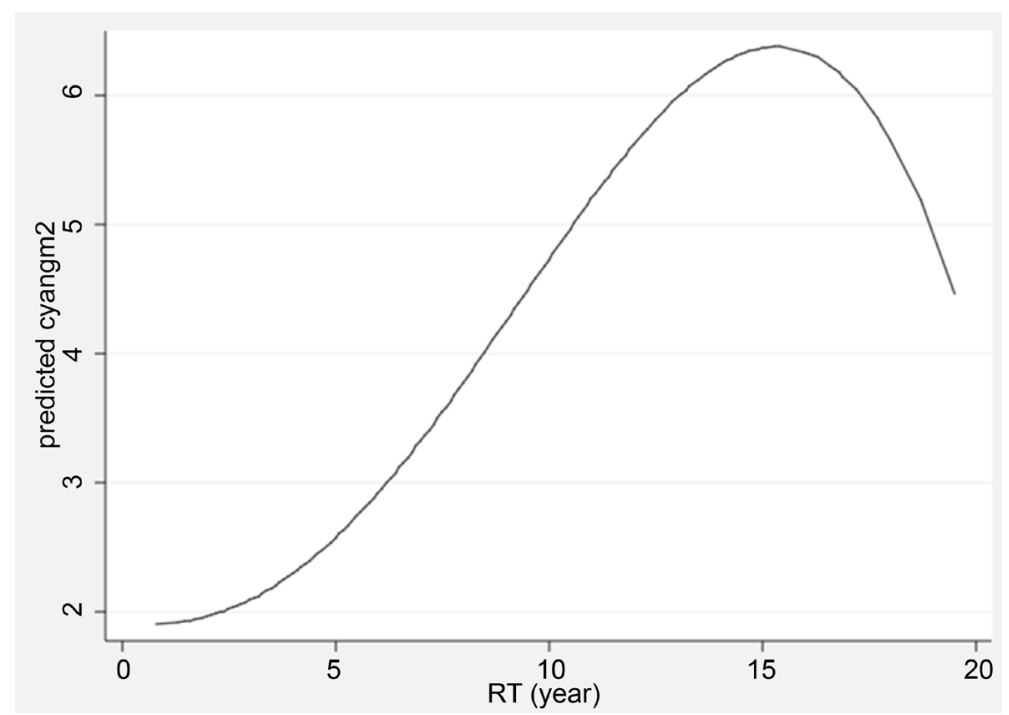

Figure 19. FP (Fractional Polynomial) regression between RT length (Years) and Cyanophyta Biomass $\left(\mathrm{g} / \mathrm{m}^{2}\right)(1969-2001)$.

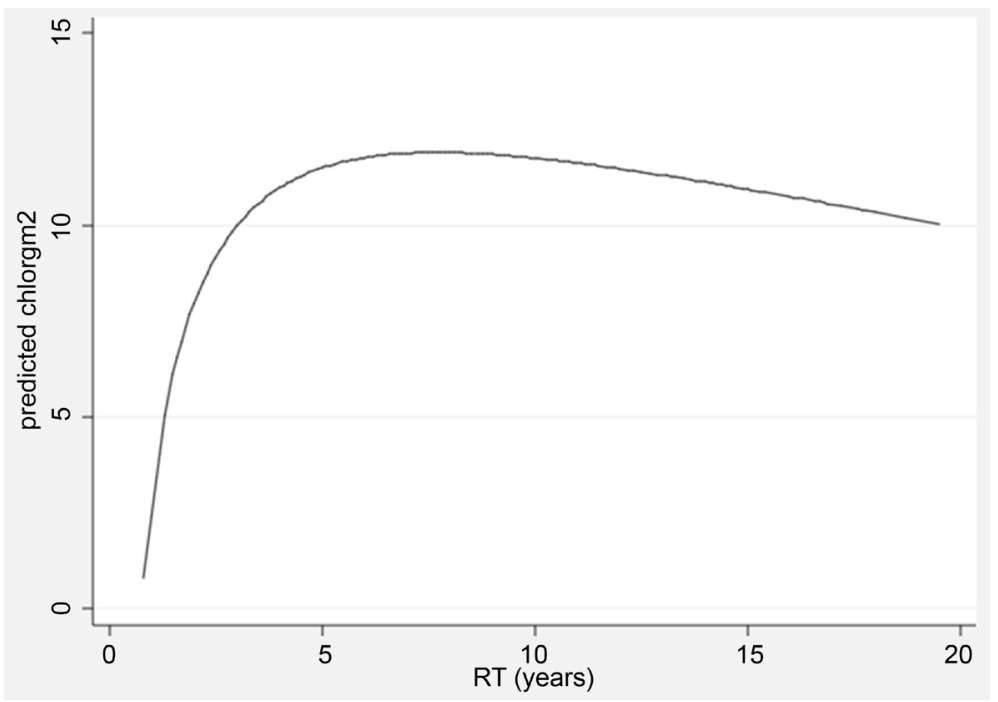

Figure 20. FP (Fractional Polynomial) regression between RT length (Years) and Chlorophyta Biomass $\left(\mathrm{g} / \mathrm{m}^{2}\right)(1969-2001)$.

It is suggested that it is due to an external supply of Silica, which is mostly supplied from the drainage basin outsourcing. Later on, when Hydrological features and Silica input diminish, Diatom biomass is reduced (Figure 18).

Cyanophyta (Figure 19): A prominent increase of the Cyanophyta Biomass (from 1.9 to $6.3 \mathrm{~g} / \mathrm{m}^{2}$ ) was documented in response to RT prolongation from 1 to 15 years accompanied by the decline of Nitrogen availability. It is likely that due to the overcome capability of Nitrogen deficiency by Nitrogen fixation maintained by Cyanophytes. The decline of the competition with Peridinium supports this as well. It is assumed that the minor decline of Cyanophytes biomass during the longest RT is due to the lack of Phosphorus when Peridinium is absent. 
Chlorophyta (Figure 20): Results in Figure 20 indicate a prominent increase in the biomass of Chlorophyta when RT becomes longer within the range of below 10 years. When RT is longer, the biomass of Chlorophyta is not enhanced persuasively, reflecting nutrient shortage conditions.

\section{Conclusive Remarks}

Hydrological parameters extracted as Residence time length were indicated as Key factor, which is responsible for the Phytoplankton dynamics in Lake Kinneret. Nitrogen sources are mostly in the drainage basin carried out into the lake by river inflows and Cyanophytes capabilities to maintain atmospheric Nitrogen fixation. Sources of Phosphorus are in the drainage basin, dust deposition and bottom sediments carried into the Epilimnion by Peridinium-mediated cells. The role of Hydrological parameters was found to be, crucially, controlling Phytoplankton dynamics.

\section{Conflicts of Interest}

The author declares no conflicts of interest regarding the publication of this paper.

\section{References}

[1] Gophen, M. (2018) Ecological Research in the Lake Kinneret and Hula Valley (Israel) Ecosystems. Scientific Research Publishing Inc., Wuhan.

[2] Serruya, C. (1978) Lake Kinneret, Monographiae Biologicae. Volume 32, Dr. W. Junk Publishers, London. https://doi.org/10.1007/978-94-009-9954-1

[3] Zohary, T., Sukenik, A., Berman, T. and Nishri, A. (2015) Lake Kinneret: Ecology and Management. Springer, New York. https://doi.org/10.1007/978-94-017-8944-8

[4] LKDB (1969-2001) Kinneret Limnological Laboratory, IOLR: Lake Kinneret Data Base and Annual Reports. Mekorot Water Supply Co. Northern Region Monitor Unit 1970-2018. Data Base, Annual Reports. Jordan River Discharges at Gesher Huri (Gesher Ha'Pkak).

[5] Gophen, M. and Gal, I. (1992) Lake Kinneret. Ministry of Defence and Kinneret Authority Publishers, Israel, 335 p. (In Hebrew)

[6] Gophen, M. (2019) Different Kinneret. Galilee Books Publishers and Migal-Scientific Research Institute, Kiryat Shmona, 158 p. (In Hebrew)

[7] Benndorf, J., Boing, W., Koop, J. and Neubauer, I. (2002) Top-Down Control of Phytoplankton: The Role of Time Scale, Lake Depth and Trophic State. Freshwater Biology, 47, 2281-2295. https://doi.org/10.1046/j.1365-2427.2002.00989.x

[8] Berman, T. (1970) Phosphtase and Phosphorus Availability in Lake Kinneret. Limnology and Oceanography, 15, 663-674. https://doi.org/10.4319/lo.1970.15.5.0663

[9] Falcover, I.B. (2005) Cyanobacterial Toxins of Drinking Water Supplies, Cylindrospermopsins and Microcystins. CRC Press, Boca Raton, FL.

[10] Gophen, M. (2015). The Impact of Available Nitrogen Defficiency on Long-Term Changes in the Lake Kinneret Ecosystem. Open Journal of Ecology, 5, 147-157. https://doi.org/10.4236/oje.2015.54013

[11] Gophen, M. (2015a) Experimental Study of the Aphanizomenon ovalisporum Re- 
sponse to Nitrogen Fertilization in the Sub-Tropical Eu-Meso-Trophic Lake Kinneret (Israel). Open Journal of Ecology, 5, 259-265.

https://doi.org/10.4236/oje.2015.56020

[12] Gophen, M. (2015b) Experimental Study of the Aphanizomenon ovalisporum Response to Nitrogen Fertilization in the Sub-Tropical Eu-Meso-Trophic Lake Kinneret (Israel), Open Journal of Ecology, 5, 259-265. https://doi.org/10.4236/oje.2015.56020

[13] Rodhe, W. (1978) Chapter: Peridinium cinctum fa westii, 4: Growth Characteristics. In: Lake Knneret. Monographiae Biologicae, Volume 32, Dr. W. Junk Publishers, London, 275-285.

[14] Serruya, C. and Berman, T. (1975) Phosphorus and Nitrogen and the Growth of Algae in Lake Kinneret. Journal of Phycology, 121, 155-1632.

[15] Serruya, C. and Pollingher, U. (1971) An Attempt at Forecasting the Peridinium Bloom in Lake 3 Kinneret (Lake Tiberias). Internationale Vereinigung für Theoretische und Angewandte Limnologie: Mitteilungen, 19, 277-291.

https://doi.org/10.1080/05384680.1971.11903936

[16] Smith, V.H. (1982) The Nitrogen and Phosphorus Dependence of Algal Biomass in Lakes: An Experimental and Theoretical Analysis. Limnology and Oceanography, 27, 1101-1112. https://doi.org/10.4319/lo.1982.27.6.1101

[17] Smith, V.H. (1983) Low Nitrogen to Phosphorus Ratios Favor Dominance by Blue-Green Algae in Lake Phytoplankton. Science, 221, 669-671.

https://doi.org/10.1126/science.221.4611.669

[18] Berman, T. (1976) Light Penetrance in Lake Kinneret. Hydrobiologia, 49, 41-48. https://doi.org/10.1007/BF00016166

[19] Rimmer, A., Gal, G., Opher, T., Leschinsky, Y. and Yacobi, Y.Z. (2011) Mechanisms of Long-Term Variations of the Thermal Structure in Awarm Lakw. Limnology and Oceanography, 56, 974-988. https://doi.org/10.4319/lo.2011.56.3.0974

[20] Havens, K.E., James, R.T., East, T. and Smith, V.H. (2003) N:P Ratios, Light, Limitation, and Cyanobacterial Dominance in a Subtropical Lake Impacted by Non-Point Source Nutrient Pollution. Environmental Pollution, 122, 379-390. https://doi.org/10.1016/S0269-7491(02)00304-4

[21] Serruya, C., Goiphen, M. and Pollingher, U. (1980) Lake Kinneret: Carbon Flow Patternand Ecosystem Management. Archiv fur Hydrobiologie, 88, 265-302.

[22] Gophen, M. (2014) Competitive Consumption of the Lake Kinneret (Isrel) Plankton by Hypophthalmichthys Molitrix and Sarotherodon galilaeus. Open Journal of Ecology, 4, 532-542. https://doi.org/10.4236/oje.2014.49043

[23] Gophen, M., Smith, V.H., Nishri, A. and Threlkeld, S.T. (1999) Nitrogen Deficiency, Phosphorus Sufficiency, and the Invasion of Lake Kinneret, Israel, by $\mathrm{N}_{2}$-Fixing Cyanobacterium Aphanizomenon ovalisporum. Aquatic Sciences, 61, 293-306. https://doi.org/10.1007/PL00001326

[24] Taranun, Z.E., Gregory, E., Leavitt, P.R., Buchaca, T., Katalan, J., Guilizzoni, P., Lami, A., McGowan, S., Moorhouse, H., Murabito, G., Mark, F.R., Stevenson, A., Thompson, P.L. and Vinerbrook, R.D. (2015) Acceleration of Cyanobacterial Dominance in North Temperate-Subarctic Lakes during the Anthropocene. Ecology Letters, 18, 375-384.

[25] Ganor, E., Foner, H.A. and Gravenhost, G. (2003) The Amount and Nature of the Dustfall on Lake Kinneret (the Sea of Galilee), Israel: Flux and Fractionation. Atmospheric Environment, 37, 4301-4315. https://doi.org/10.1016/S1352-2310(03)00455-2 
[26] Nishri, A. (2014) Chapter 19.4.3. Atmospheric Sources: Dry Deposition (Dust). In: Zohary, T., Sukenik, A., Berman, T. and Nishri, A., Eds., Lake Kinneret. Ecology and Management, Springer, New York, 341-346.

[27] Nishri, A. and Sukenik, A. (2012) Monitoring of Selenium Species in Lake Kinneret and Its Drainage Basin. (In Hebrew)

[28] Nishri, A, Brenner, I.B., Hall, G.E.M. and Taylor, H.E. (1999) Temporal Variation in Dissolved Selenium in Lake Kinneret (Israel). Aquatic Sciences, 61, 215-233. https://doi.org/10.1007/s000270050063

[29] Nishri, A. and Gavrieli, I. (2019) Integrative Approach to the Study of the Impact of Water Bodies in the Hula Valley on Lake Kinneret. 2nd Annual Report Submitted to the Water Authority, IOLR Report No. T8-2019, 22 p. (In Hebrew)

[30] Shapiro, J. (1973) Blue-Green Algae: Why They Become Dominant. Science, 179, 382-384. https://doi.org/10.1126/science.179.4071.382 